\title{
READERS
Insight
}

Journal of Management Info (JMI)

ISSN:2313-3376

www.readersinsight.net/jmi

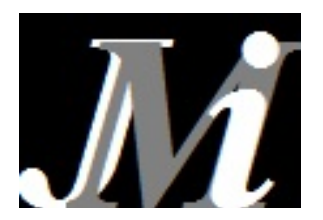

\section{Financial development and stock traded contributions towards economic growth}

\author{
Shehper Maryam Zafar ${ }^{a^{*}}$, Nadia Bukhari ${ }^{\mathrm{b}}$ \\ A Shehper Maryam Zafar, COMSATS Institute of Information Technology, Department of Management Sciences, 43600, Attock, Pakistan. \\ b Nadia Bukhari, COMSATS Institute of Information Technology, Department of Management Sciences, 43600, Attock, Pakistan. \\ ${ }^{*}$ Corresponding author:
}

\begin{abstract}
This purpose of this research is to check the long run as well as the short run impact of Financial Development and Stock Traded on the economic growth in the scenario of Pakistan. The time series data is taken for the years 1988-2013. This paper utilized ARDL methodology to determine long term impact of Financial Development and Stock Traded on Economic growth. Further Granger Causality Check is used to check a uni-directional relationship. The results of this test support that FD and stock traded has a uni-directional impact over economic growth. Further it is depicted from ARDL that there is a positive relationship between FD and Economic Growth as well as Stock Traded and Economic Growth.
\end{abstract}

\section{ARTICLE INFORMATION}

Received: 25 January 2015

Revised: $\quad 25$ February 2015

Accepted: 1 March 2015

DOI:

http://dx.doi.org//10.31580/jmi.v5i1.34

\section{Introduction}

Consistent with considering of the recent growth theorists, a well groomed economic sector eases high though viable increase. The connection between development as well as finance has been arguments in economic and financial literature. Some researchers believed that a wonderful dichotomy is present with respect to the perspective of monetary Intermediaries in facilitating economic development for long period. The contributions of (Mckinnon and Shaw, 1973) with respect to the connections among financial improvement as well as Economical growth, is a significant problem of discussion in developing Economic systems. For linking economic improvement to growth, the argument is that a well-improved economic program performs numerous essential features to improve efficacy by reducing information, trade, and tracking costs. The money market performs a crucial part in the enhancement of trade and industry which finally Changes the country's market to big extent. That is the reasoning the Government advisers as well as the country's issuing authority have a keen eye in the actions of the Market. This paper investigates the connection between the financial development, stock traded and Economical growth for the time period of 1988-2013 in Pakistan.

Since 1947, Pakistan is fighting for the economical development though it had to face problems. From the previous year, in 2014 Gross Domestic Product (GDP) rose 5\% in Pakistan. Economical growth in Pakistan is $4.93 \%$ on common from 1952 to 2014 , it attained to its summit to $10.22 \%$ in 1954 and touched its base to $-1.80 \%$ in 1952 . Pakistan Bureau of Statistics reviews financial development (GDP). (Khan, et al. 2005) has examined an empirical connection concerning financial improvement as well as growth rate pertaining to the period of 1971-2004 in Pakistan. This research study is also illustrating the work on all these three variable Financial Development, Stock Traded and Economic Growth. This study is different in a way that it analyzed all these three variables together in the scenario of Pakistan for the period of 1988-2013.

The first portion of this paper includes the literature review in which the previous work over this topic is discussed. At the second step variable construct is made in which all variable are discussed in details and the work on these variables with reference of the work done in the past. At the third stage estimation strategy is made in which models and testing procedures are mentioned in detail. The fourth stage is very important which illustrate the empirical results obtained by applying models. The results are mention and at the last step the conclusion is drawn with some suggestions and policies.

\section{Literature review}

Goldsmith(1969) as well as Mckinnon(1973) and Shaw(1973) are the pioneer contributors for studying the link among the financial enhancement and economic development. Still it is a main issue of debate in advancing economies. Modern economic climate boost investment through directing beneficial business offerings, hedging, allowing the buying and selling, monitoring the performance of managers, diversification of risk, facilitate the trading involving products and services. These kind of operations developed in the highly cost effective allocation of assets like physical as well as human capital in addition to the faster scientific advancement, which boost economic growth.[ Creane, et al. (2004)]. Financial advancement and economic growth suffers an argument. King and Levine (1993), Mc Kinnon (1973) and Shaw (1973) consider finance as a necessary component of growth while Lucas (1988) considers it a minor factor of growth. Further financial advancement consist of a better and also beneficial influence on total factor productivity for the nourishment over all GDP. (Neusser and Kugler, 1998), ( Beck, et al. 2000). (Khan, et al. 2005) has examined an empirical connection concerning financial improvement as well as growth rate pertaining to 
the period of 1971-2004 in Pakistan. The study illustrates an optimistic impression regarding fiscal level upon economic development. Another study during the period of 1979-2008 depicts the relationship between the financial advancement and the economic improvement by making use of auto regression distributed lag (ARDL). It is found that an exclusive co-integrating connection exists between financial enhancement as well as GDP. (Azher Mehmood, 2009). Another paper include the study for ten developing countries over the relationship between financial depth and GDP using pool unit root test as well as pool co integration study with modified OLS model. Single equilibrium relation among monetary improvement and growth was determined. There is a one way relation among monetary depth as well as growth. (Christopoulos and Tsionas, 2004). (Filer, et al. 1999) in his study depicts the strong relationship between stock traded in stock market and economic development in future for low income or middle income countries. Many empirical findings examined the connection between monetary improvement and economic development which demonstrate the vague results. The panel data and a cross country studies favor positive impact of financial enhancement on GDP (King and Levine, 1993), (Khan and Senhodji, 2000, Levine, et al. 2000) at the same tine, time series analysis provide contradictory findings. This study shows very little favor for the optimistic connection among financial improvement and GDP. (Demitriades and Hussein, 1996). In the broader consensus stock market performance affects the economy and its influence is gradually increasing "confidence affect" forming one of these influencing factors. Continuous stock market declines can be expressed as a forerunner of economic decline which in turn lowers consumer's confidence and decrease consumption, investment and stock trading. (Holger Sandte, 2012). Capital marker plays a vital role in the commerce and industrial development which have a larger influence on economy. The central bank, industrial bodies and government advisors keep a keen eye on stock market activities. This paper determines the connection among financial advancement and fiscal growth in Pakistan for 1986-2008. It concludes that economic growth or GDP can be achieved by increasing and developing stock market, size of country and the market capitalization in an emerging market like Pakistan. (Nazir,et al. 2010). The result supports the positive relation of financial development and stock traded with GDP.

\section{Variable construct}

Three variables are studied in this paper, economic growth as dependent variable and financial development and stock traded as independent variable.

(Tatyana 2000) provides two proxies for determining economic enhancement, GNP (gross domestic product) as well as GDP (gross domestic product).He define economic growth as "quantitative expansion in nation's economy". Furthermore Goldsmith(1969) as well as Mckinnon(1973) and Shaw(1973) are the pioneer contributors for studying the link among the financial enhancement and economic development.

For determining economic growth we mostly take GDP since it is considered best proxy to determine economic development. (Oulton, 2012) .Researcher asserts the actual result that GDP gather all sort of production giving better picture of economic growth. Paul Samuelsson author of numerous books as well as research papers also counted GDP as being a better measure for expansion of a rustic. (Rati Ram, 2007) studied the outcome of monetary development on economic enhancement and used GDP since the indicator of monetary development where by GDP is additionally the way of measuring financial enhancement. (Khan et al. 2005) also determined the connection and impact of financial enhancement on economic growth and used domestic credit private sector percentage for GDP as the proxy for determining financial boost and per capita real GDP for economic development. Another research paper by (Azhar Mehmood, ) depicted the association between financial development and economic development for many years of 1979-2008. Financial enhancement within this paper includes institutions expansion as well as establishment, markets and also instruments offering support to this particular procedure for growth as well as investment nonetheless they determined economic development by GDP. There many studies analyzed the empirical connection among long-run development and financial enhancement, proxied from the ratio among bank credit towards the private sector as well as GDP. Particularly, government hindrance for the banking system including rate of interest ceiling, larger reserve needs and also directed credit programs include the factors affecting financial enhancement and influencing output growth [Mckinnon(1973) and Shaw (1973)]. The challenge using the previous studies is the fact that a confident and optimistic relationship among financial enhancement and output growth are available for various reasons. As output raises, the requirement for financial services rises too, as a result it features a positive relation to financial improvements. (Robinson, 1952). Keeping in view all the above research studies on hand preferred to take per capita real GDP as a proxy of economic growth as well as Domestic credit private sector percentage for GDP as a proxy of financial development.

Stocks traded are an indicator for stocks market development and an emerging variable which is being included in researches and studies in recent times. Based on my home work related to this particular variable, I am also using stocks traded as independent variable in my studies finding it appropriate and useful. (Filer, et al. 1999) added stocks traded as independent variable in the studies and depicted a strong connection between stock traded in stock market and economic development in future for low income or middle income countries. (Nazir, et al. 2010) used stocks traded to represent participation of capital markets and their significance on economic enhancement. The study was conducted in Pakistani context. The out comings of the research showed a very strong positive relation in stocks traded, financial enhancement and GDP.

(Men \& Li, 2006) also examined the relation between nation's economy and stocks traded using certain tests mainly co integration test. The study was carried on in Chinese framework. Another author (Tachiwou, 2010) tried to use stocks traded and GDP for estimating the relation among stocks market growth and economic enhancement in West African background. (Levin et al. 2000) studied the causes and causalities for growth of stocks traded in capital markets.

\section{Estimation strategy}

Estimation Strategy: Autoregressive Distributed Lag (ARDL) methodology is a new approach which was first introduced by (Pesaran and Pesaran, 1997) then (Pesaran and Smith, 1998), (Pesaran and Shin, 1999), as well as (Pesaran et al. 2001) worked on it. This technique relies on the general-to- specific modeling method. In this paper, in order to find out the long run impacts of financial enhancement as well as the stock traded on economic growth, ARDL technique is applied.

The ARDL approach has an edge over several other approaches of cointegration. i) It is generally used no matter whether the primary variables are typically $\mathrm{I}(0)$ as well as $\mathrm{I}(1)$ or even an amalgam of each (Pesaran and Pesaran 1997). ii) This particular approach contains satisfactory lags as a way to include the entire information generating procedure, generally to modeling frameworks. iii) Error Correction Model (ECM) is the outcome of a basic derivation which ally short run improvements as well as long run steadiness without compromising long run information as well as facts. iv) The minimum sample properties from ARDL technique is considered more advanced than those of Johensen as well as Juselius cointegration approach (Pesaran and Shin, 1999). v) Endogeneity, in which the independent variable depends upon the error term, is recognized as a lesser concern for the ARDL methodology because it is without any error dependency. Where as in a study by (Pesaran and Shin, 1999) depicted the concurrent estimation of long-run and also the short-run factors as well as acceptable gaps in ARDL structure eradicate the issues which is related to serial correlation as well as endogeneity issues. vi) The ARDL methodology can positively discern among dependent as well as independent variables. The model will be written as: 
$\Delta G D P_{i}=\beta_{0}+\sum_{i=1}^{p} \delta_{i} \Delta G D P_{t-i}+\sum_{i=1}^{p} \phi_{i} \Delta F D_{t-i}+\sum_{i=1}^{p} \phi_{i} \Delta S 7$

Here $B_{0}$ is representing the constant and $\mu t$ is representing white noise. The terms having summation signs show the residual amendment dynamics, while in the second portion $\lambda$ is depicting long run connections. The very first point in ARDL is check stationarity by Unit Root Test in order to fend off the spurious relationship. Another point in ARDL is that it is required to test this technique and execute F-tests on the current long run connections among the variables.

The null hypothesis cab be written as $\mathrm{H}_{0} \quad: \lambda 1=\lambda 2=0$. This hypothesis depicts the existence of long run connections. The alternative hypothesis can be written as $\mathrm{H}_{1}: \lambda 1 \neq 0, \lambda 2 \neq 0$.

The F-statistics is executed and then it is compared with the two pairs of critical values (Pesaran et al. 2001). One pair contains I(0) series where the other one contains I(1)series. In case if F-statistics lies in the upper critical value, we would reject our null hypothesis, depicting zero cointegration. Regardless the variables are either $\mathrm{I}(0)$ or I(1) it is executed. But $\mathrm{H}_{1}$ will be accepted if F-statistics would be lowed than critical values. But the test is said to be inconclusive if the value lies in the critical value band (Pesaran and Pesaran, 1997). ARDL methodology determines $(\mathrm{p}+1) \mathrm{k}$ regressions in order to obtain most appropriate lag length for every single variable. SBC measures nominal lag length but AIC calculates the greatest suitable lag length. Further more, long run can be estimated through SBC and AIC by using ARDL approach. Error correction representation is required when estimating long run.

$$
\Delta G D P_{i}=\beta_{0}+\sum_{i=1}^{p} \delta_{i} \Delta G D P_{t-i}+\sum_{i=1}^{p} \phi_{i} \Delta F D_{t-i}+\sum_{i=1}^{p} \phi_{i} \Delta S 7
$$

Error correction term ECM demonstrates the adjustment of long run stability from a short run shock. Diagnostic as well as stability tests are performed in order to check goodness of fit and check the over all explanatory power of model. This method is famous as cumulative sum (CUSUM) as well as cumulative sum of squares (CUSUMSQ). If the values of the CUSUM and CUSUMSQ statistics lies in the critical region having $5 \%$ significance level, so the null hypothesis of every coefficient will be accepted. For the application of these estimation methods, World Development Indicators are used to gather time series data.

\section{Empirical results}

All the variables Stock traded, FD and GDP are non stationary at its level but eventually become stationary at its first difference.

\section{Stationary analysis}

\begin{tabular}{|l|l|l|l|l|}
\hline Variables & Level & $\mathrm{K}$ & $1^{\text {st }}$ difference & $\mathrm{K}$ \\
\hline Stock traded & -4.0362 & 1 & -2.0617 & 0 \\
\hline FD & -2.902 & 1 & -0.2923 & 0 \\
\hline GDP & -2.7889 & 1 & -2.4986 & 0 \\
\hline
\end{tabular}

\section{Granger causality test}

\begin{tabular}{|l|l|l|}
\hline Hypothesis & F-statistics & Probability \\
\hline $\begin{array}{l}\mathrm{H}_{\mathrm{o}} ; \text { FD doesn't granger } \\
\text { cause GDP }\end{array}$ & 6.3748 & 0.6787 \\
\hline $\begin{array}{l}\mathrm{H}_{\mathrm{A}} \text { GDP doesn't } \\
\text { granger cause FD }\end{array}$ & 0.4536 & 0.9436 \\
\hline
\end{tabular}

It is still not discovered whether FD has impact over Economic growth or Economic growth has impact over FD. So for checking out the uni-directional relationship among variables Granger Causality test is employed. The values of F-statistics as well as probability are obtained. The results illustrated that $\mathrm{H}_{\mathrm{o}}$ is rejected and supporting a uni-directional result that FD has an influence on GDP.

\section{Long run and short run results of ARDL}

\begin{tabular}{|l|l|l|}
\hline Dependent variable is GDP & T-values \\
\hline Regressors & Coffecient Value & 26.2907 \\
\hline Constant & 1.0286 & 0.0893 \\
\hline FD & 0.2954 & 0.6277 \\
\hline Stock Traded & 0.1243 & \\
\hline Diagnostic tests & P-Values \\
\hline Serial correlation & 0.0224 \\
\hline Functional Form & 1.2664 \\
\hline Normality & 2.2135 \\
\hline Hetroskedesticity & 0.7566 \\
\hline
\end{tabular}

Long run equation is estimated using ARDL methodology in order to get long run results. Inorder to get the coffecients' values of variables Quinn criterion, SBC criterion, AIC criterion and $\mathrm{R}^{2}$ criterion is used. The results of both the models of short run as well as long run are almost same.

In the long run the value of coffecient of constant is 1.0286 which means if FD and Stock Traded has no impact on GDP then even though GDP will be 1.0286 . The coffecient of FD is 0.2954 which means $1 \%$ increase in FDI will lead to increase GDP by $29.54 \%$ where as the coffecient of Stock Traded is 0.1243 which means $1 \%$ increase in FD will lead to increase GDP by $12.43 \%$. Diagnostic Test is performed in order to check serial correlation, functional form, normality and Hetroskedisticity. The results from these tests showed that there is no serial correlation and functional form, the data is normally distributed and there is no problem of hetroskedesticity.

In short run results the coffecient of FD in short run is 0.0259 so it means $1 \%$ increase in FDI will lead to increase GDP by $2.59 \%$. Similarly the coffecient of Stock Traded is 0.0152 which means that $1 \%$ increase in FD will lead to increase GDP by $1.52 \%$. The value of ECM is -0.1862 show that there is a significant relationship among variables. $18 \%$ will be corrected in one year so $100 \%$ will take almost 5 years to be corrected. Further the results of $\mathrm{R}^{2}$ show that FDI significantly determine GDP and the results from Durbin-Watson test depicts that there is no auto correlation exists between variable.

Plot of Cumulative Sum of Recursive Residuals

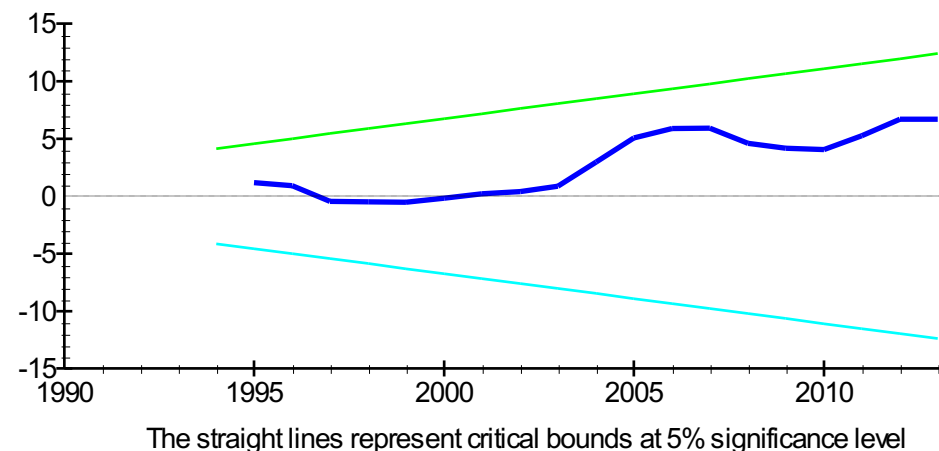

Fig. 1. 
Plot of Cumulative Sum of Squares of Recursive Residua

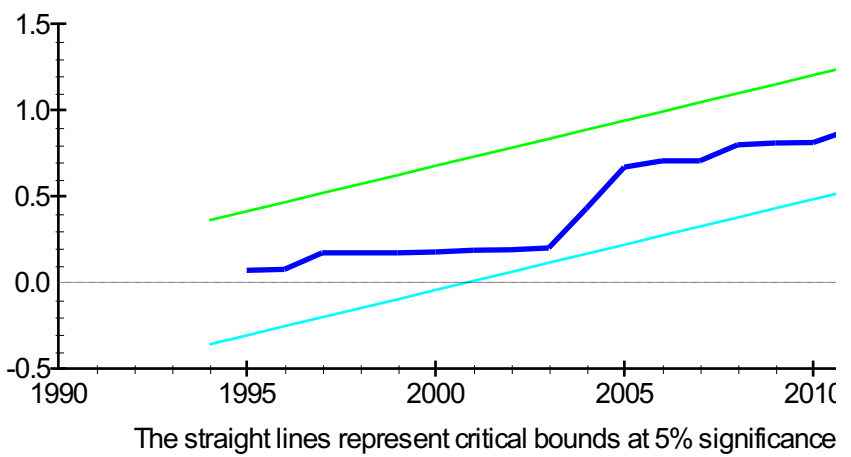

Fig. 2.

\section{Conclusion}

The basic purpose of this study is to analyze that how Financial Development and Stock Traded contribute to Economic Growth. The study is conducted in the scenario of Pakistan for the period of 19882013. This paper worked on ARDL technique in order to check the long run as well as short run relationship among variables. The empirical results suggest that there exist a long run relationship among variables. Granger causality test is employed and the results showed that there is a uni-directional relationship among variables so FD impacts on GDP and so is Stock Traded. CUSUM and CUSUMSQ techniques which are applied on ECM show that coefficients of Model are sound. The empirical results depicted that FD and Stock Traded has a positive impact on GDP.

This paper would be beneficial for analyzing the long run impact of FD and Stock Traded on GDP in case of Pakistan. It further supports that FD and Stock Traded positively influence the Economic growth. Moreover, there is a room for study for the new researchers. In this study while analyzing FD data is taken as a whole, but if the data is taken from a particular sector the results could be better. Further Stock traded are analyzed in the scenario of Pakistan but in future stock traded can be studied on international level.

\section{References}

Beck, T., R. Levine, and N. Loyaza (2000) Finance and the Sources of Growth. Journal of Financial Economics 58, 261-300.

Christopoulos, D. K., \& Tsionas, E. G. (2004). Financial development and economic growth: evidence from panel unit root and cointegration tests. Journal of development Economics, 73(1), 55-74.

Creane, S., Goyal Rishi, A. Mushfiq Mobarak, and Randa Sab (2004) Financial Sector Development in the Middle East and North Africa. International Monetary Fund, Washington, D.C. (IMF Working Paper 04/201.)

Demetriades, P. O., and A. K. Hussein (1996) Does Financial Development Cause Economic Growth? Time Series Evidence from 16 Countries. Journal of Development Economics 51, 387-411.
Filer, R. K., Hanousek, J., \& Campos, N. F. (2000). Do stock markets promote economic growth?. CERGE-EI Working Paper Series, (151).

Goldsmith, R. W. (1969) Financial Structure and Development. New Haven, C.T.: Yale University Press.

De Gregorio, J., \& Guidotti, P. E. (1995). Financial development and economic growth. World development, 23(3), 433-448.

Khan, S. M., and A. S. Senhadji (2000) Financial Development and Economic Growth: An Overview. International Monetary Fund, Washington, D. C. (IMF Working Paper 00/209.)

Khan, M. A., Qayyum, A., Sheikh, S. A., \& Siddique, O. (2005). Financial Development and Economic Growth: The Case of Pakistan [with Comments].The Pakistan Development Review, 819-837.

King, R. G., and R. Levine (1993a) Finance, Entrepreneurship and Growth. Journal of Monetary Economics 32, 30-71.

Levine, R., Norman Loayza, and Thorsten Beck (2000) Financial Intermediation and Growth: Causality and Causes. Journal of Monetary Economics 46, 31-77.

Men, M., \& Li, R. (2006). An Empirical Study on the Relationship between Stock Index and the National Economy: The Case of China. University of International Business \& Economics, Beijing, People's Republic of China.

Mian, S. N., Muhammad, M. N., \& Usman, J. G. (2010). Relationship between economic growth and stock market development. African Journal of Business Management, 4(16), 3473-3479.

Mahmood, A. (2013). Impact of Financial Development on Economic Growth of Pakistan. Abasyn Journal of Social Sciences, 6(2), 106-116.

Mckinnon, R. I. (1973) Money and Capital in Economic Development. Washington, D. C.: Brooking Institution.

Neusser, K., and M. Kugler (1998) Manufacturing Growth and Financial Development: Evidence from OECD Countries. The Review of Economic and Statistics 638-646.

Oulton, N. (2012). Long term implications of the ICT revolution: applying the lessons of growth theory and growth accounting. Economic Modelling, 29(5), 1722-1736.

Rajan, R. G., \& Zingales, L. (1996). Financial dependence and growth (No. w5758). National bureau of economic research.

Shaw, E. S. (1973) Financial Deepening in Economic Development. Cambridge, M.A.: Havard University Press.

Tachiwou, A. M. (2010). Stock market development and economic growth: the case of West African monetary union. International Journal of Economics and Finance, 2(3), p97.

Pesaran, M.H., Pesaran, B., 1997. Working With Microfit 4.0: Interactive Econo- metric Analysis. Oxford University Press, Oxford.

Pesaran, M.H., Shin, Y., 1999. An autoregressive distributed lag modelling approach to cointegration analysis. In: Strom, S. (Ed.), Econometrics and Economic Theory in 20th Century: The Ragnar Frisch Centennial Symposium. Cambridge University Press, Cambridge Chapter 11.

Pesaran, M.H., Smith, R.P., 1998. Structural analysis of cointegrating VARs. Journal of Economic Survey 12, 471-505.

Pesaran, M.H., Shin, Y., Smith, R.J., 2001. Bounds testing approaches to the analysis of level relationships. Journal of Applied Econometrics 16, 289 326.

Peia, O., \& Rozsbach, K. (2013). Finance and Growth: Time Series Evidence on Causality. Available at SSRN 2206221.

Ram, R. (2007). IQ and economic growth: Further augmentation of MankiwRomer-Weil model. Economics Letters, 94(1), 7-11. 